\title{
Production of mutants in amino acid biosynthesis genes of Mycobacterium tuberculosis by homologous recombination
}

\author{
Tanya Parish, ${ }^{1}$ Bhavna G. Gordhan, ${ }^{2}$ Ruth A. McAdam, ${ }^{3}$ Ken Duncan, ${ }^{3}$ \\ Valerie Mizrahi ${ }^{2,4}$ and Neil G. Stoker ${ }^{1}$
}

1 Department of Infectious and Tropical Diseases, London School of Hygiene \& Tropical Medicine Keppel Street, London WC1E 7HT, UK

2 Molecular Biology Unit, South African Institute for Medical Research, PO Box 1038, Johannesburg 2000, South Africa

3 Immunopathology Unit, Glaxo Wellcome Research and Development, Medicines Research Centre, Stevenage, UK

4 Department of Haematology and Molecular Medicine, University of the Witwatersrand, Johannesburg, South Africa Author for correspondence: Neil G. Stoker. Tel: +44207927 2425. Fax: +44 2076374314.
e-mail: neil.stoker@1shtm.ac.uk

The ability to generate mutants of Mycobacterium tuberculosis will be important if we are to understand the biology of this major pathogen. However, allelic replacement methods have only recently achieved success. We have developed a reproducible method for generating defined mutants of M. tuberculosis using homologous recombination. The transforming DNA was used following pre-treatment either with UV light or alkali denaturation in order to stimulate homologous recombination and abolish illegitimate recombination. Suicide vectors carrying one of nine amino acid biosynthesis genes were electroporated into $M$. tuberculosis, and homologous recombinants were obtained in all nine genes; eight resulted from singlecrossover events (SCOs) and one from a double-crossover event (DCO) (in the metB gene). The remaining colonies were spontaneous hygromycin-resistant mutants; no products of illegitimate recombination were observed. To more efficiently distinguish spontaneous mutants, the lacz gene was cloned into five vectors (two containing genes not previously tested), and the transformations were repeated. SCO mutants were identified by screening for blue colonies on indicator plates. White transformants were tested for auxotrophy and trpD, hisD and proC auxotrophic mutants were obtained. Only blue SCOs were obtained for argF and gInE. Thus, using this methodology we have obtained homologous recombination in 11 genes, and DCOs in 4 genes, showing that it is possible to generate targeted mutants in a reproducible way.

Keywords: auxotrophs, gene replacement, lacZ, Casamino acids, pre-treated DNA

\section{INTRODUCTION}

An understanding of the genetics of Mycobacterium tuberculosis is important both for characterization of potential drug targets and for a deeper knowledge of the mechanisms by which the bacterium establishes an infection and causes disease. The ability to inactivate genes at will is a key requirement for this, made even more desirable by the data which are now available following the completion of the genome sequence (Cole et al., 1998). Gene replacement has not proved to be straightforward in mycobacteria, and has only recently been achieved in M. tuberculosis (Balasubramanian et

Abbreviations: DCO, double crossover; $\mathrm{HR}$, homologous recombination; IR, illegitimate recombination; hyg $^{R}$, hygromycin resistant; SCO, single crossover. al., 1996; Hinds et al., 1999; Pavelka et al., 1999; Pelicic et al., 1997). Illegitimate recombination (IR) has been demonstrated in M. tuberculosis and appears to occur at a relatively high rate (Kalpana et al., 1991). Early reports suggested that IR did not occur in Mycobacterium smegmatis, but we have shown that IR also occurs in this fast-growing species at a low level (Hinds et al., 1999). Where the rate of IR exceeds that of homologous recombination (HR), the isolation of knockout mutants becomes a problem.

We have previously shown that pre-treatment of the transforming DNA increases the rate of HR, which enabled us to isolate mutants in three mycobacterial species: M. smegmatis, Mycobacterium intracellulare and M. tuberculosis (Hinds et al., 1999). Although we had obtained a tlyA mutant of M. tuberculosis using 
pre-treated DNA (Hinds et al., 1999), it was important to look at different genes in order to assess the general applicability of this delivery system. Here we describe the use of DNA pre-treatment to test our system with a further 11 genes and present an improved procedure for simply and reliably isolating targeted mutants of $M$. tuberculosis. We selected genes involved in amino acid biosynthesis as our candidates for knockouts because mutants in these genes may be attenuated in vivo as has been documented for Salmonella typhimurium (O'Callaghan et al., 1988). Such mutants would provide important information regarding the host environment encountered by the bacterium and may be potentially useful in new vaccine development. The additional advantages were that mutants would have easily testable phenotypes and the genes are unlikely to be essential on rich media in vitro.

\section{METHODS}

Bacterial strains and plasmids. Plasmids used in this study are listed in Table 1. Middlebrook 7H9 broth and Middlebrook 7H10 agar (Difco) plus 10\% OADC supplement (Becton Dickinson) and $0.05 \%$ Tween 80 for liquid media were used for culture of $M$. tuberculosis. Hygromycin was added to $50-100 \mu \mathrm{g} \mathrm{ml}^{-1}$ and X-Gal at $50 \mu \mathrm{g} \mathrm{ml}^{-1}$ where appropriate. Filter sterilized Casamino acids were used at $40 \mu \mathrm{g} \mathrm{ml}^{-1}$ and individual amino acids were used at $50 \mu \mathrm{g} \mathrm{ml} \mathrm{m}^{-1}$. 'Aro' supplement consisted of the three amino acids L-tryptophan, L-phenylalanine and L-tyrosine at $50 \mu \mathrm{g} \mathrm{ml}^{-1}$ each and $p$ aminobenzoic acid at $100 \mu \mathrm{g} \mathrm{ml}^{-1}$.

Construction of delivery vectors. Cosmids were obtained from the Sanger Centre and restriction fragments were subcloned into pGEM3Zf $(+)$, pGEM5Zf $(+)$ or pUC18 by standard methods (Sambrook et al., 1989). The hygromycin resistance gene (byg) from pAGAN40 (Hinds et al., 1999) was then cloned into each gene.

Construction of lac $\boldsymbol{Z}$ delivery vectors. The complete
Escherichia coli lacZ gene from plasmid pATB12 (Martin Everett, Glaxo Wellcome) was cloned as a HindIII fragment into the HindIII site of five suicide vectors (Table 2) and expression of $l a c Z$ confirmed in E. coli as demonstrated by the formation of blue colonies on X-Gal plates. The lac promoter is not itself functional in mycobacteria, so we assume that $l a c Z$ expression in mycobacteria occurs from a cryptic promoter.

Electroporation of $\boldsymbol{M}$. tuberculosis H37Rv. Liquid cultures $(10 \mathrm{ml})$ were inoculated from plates and cultured standing for 4-6 weeks at $37^{\circ} \mathrm{C}$. One millilitre of this culture was used to inoculate a further $10 \mathrm{ml}$ and used as the seed culture. One hundred millilitre cultures were inoculated with $1-10 \mathrm{ml}$ of seed culture and grown in a roller bottle for 4-7 d. Glycine was added to $0 \cdot 2 \mathrm{M} 24-72 \mathrm{~h}$ prior to harvesting. Cultures were harvested, washed in $1 / 10 \mathrm{vol} 10 \%$ glycerol (prewarmed to $37^{\circ} \mathrm{C}$ ), then $1 / 20 \mathrm{vol}$ and finally resuspended in $1-2 \mathrm{ml} 10 \%$ glycerol. Pre-treated DNA $(1-5 \mu \mathrm{g})$ was added to $200 \mu \mathrm{l}$ cell suspension and subjected to a pulse of $2.5 \mathrm{kV}, 25 \mu \mathrm{F}, 700 \Omega$ using a Bio-Rad Gene Pulser at room temperature. Cells were recovered into $10 \mathrm{ml} 7 \mathrm{H} 9 / \mathrm{OADC} / \mathrm{Tw}$ ween containing supplements as required and incubated at $37^{\circ} \mathrm{C}$ for $3-24 \mathrm{~h}$ before plating onto $7 \mathrm{H} 10 / \mathrm{OADC}$ plus appropriate antibiotics and supplements. Plates were incubated at $37^{\circ} \mathrm{C}$ for 3 weeks.

Treatment of transforming DNA. Vector DNA was treated prior to transformation as described (Hinds et al., 1999). Briefly, UV irradiation of DNA was carried out in an UV Stratalinker 1800 (Stratagene) at $100 \mathrm{~mJ} \mathrm{~cm}^{-2}$. Alkali denaturation was performed in a $100 \mu \mathrm{l}$ volume containing $0 \cdot 2 \mathrm{M}$ $\mathrm{NaOH}, 0.2 \mathrm{mM}$ EDTA at $37^{\circ} \mathrm{C}$ for $30 \mathrm{~min}$, followed by ethanol precipitation.

Analysis of transformants. Transformants were inoculated into $10 \mathrm{ml}$ liquid media (plus hygromycin and supplements) and cultured standing at $37^{\circ} \mathrm{C}$ for DNA preparation by the method of Belisle \& Sonnenberg (1998) or Santos et al. (1992). Southern blotting was carried out using probes labelled by the AlkPhos Direct method (Amersham). Initial auxotrophy testing was carried out by patching transformant colonies onto $7 \mathrm{H} 10 / \mathrm{OADC}$ plates with and without the appropriate supplements and cultured at $37^{\circ} \mathrm{C}$ for $3-4$ weeks before

Table 1. Plasmids used in this study

\begin{tabular}{|c|c|c|}
\hline Plasmids & Description & Source/reference \\
\hline pGEM3Zf $(+)$ & Phagemid vector, $\mathrm{Ap}^{\mathrm{R}}$ & Promega \\
\hline pGEM5Zf $(+)$ & Phagemid vector, $\mathrm{Ap}^{\mathrm{R}}$ & Promega \\
\hline pUC18 & Cloning vector, $\mathrm{Ap}^{\mathrm{R}}$ & Stratagene \\
\hline pAGAN40 & E. coli-mycobacteria shuttle vector, $h y g$ & Hinds et al. (1999) \\
\hline pARG7 & $\arg F:$ : hyg suicide delivery vector, $\operatorname{lac} Z$ & This work \\
\hline pAROB2 & aroK:: hyg suicide delivery vector & This work \\
\hline pGLN2 & $g \ln E::$ byg suicide delivery vector & This work \\
\hline pGLN7 & $g \ln E:$ : hyg suicide delivery vector, lacZ & This work \\
\hline pHIS2 & hisD:: hyg suicide delivery vector & This work \\
\hline pHIS7 & hisD: : hyg suicide delivery vector, $\operatorname{lac} Z$ & This work \\
\hline pSELF23 & met $B:$ : hyg suicide delivery vector & This work \\
\hline pLYS3 & lys $A:$ : byg suicide delivery vector & This work \\
\hline pPHE2 & pheA:: hyg suicide delivery vector & This work \\
\hline pPRO7 & proC:: hyg suicide delivery vector, $\operatorname{lac} Z$ & This work \\
\hline pTHR4 & thrC:: hyg suicide delivery vector & This work \\
\hline pTHR5 & thrB::hyg suicide delivery vector & This work \\
\hline pTRP2 & $\operatorname{trpD}:$ : hyg suicide delivery vector & This work \\
\hline pTRP7 & $\operatorname{trpD}:$ : hyg suicide delivery vector, $\operatorname{lac} Z$ & This work \\
\hline
\end{tabular}


Table 2. Construction of suicide delivery vectors

\begin{tabular}{|c|c|c|c|c|c|c|c|}
\hline Plasmid & Gene & $\begin{array}{c}\text { Rv ORF } \\
\text { no. }\end{array}$ & Cosmid* & Fragment & $\begin{array}{l}\text { Size } \\
(\mathrm{bp})\end{array}$ & $\begin{array}{c}\text { Vector } \\
\text { used }\end{array}$ & $\begin{array}{l}\text { Type of } \\
\text { mutation } \dagger\end{array}$ \\
\hline pARG7 & $\arg F$ & 1656 & $6 \mathrm{H} 11$ & BamHI-BglII & 3812 & $\operatorname{pGEM} 3 Z f(+)$ & 156 bp deletion \\
\hline pAROB2 & $\operatorname{aroK}$ & $2539 c$ & Y159 & $S p h \mathrm{I}$ & 2780 & pGEM5Zf $(+)$ & 324 bp deletion \\
\hline pGLN2 & $g \ln E$ & $2221 c$ & Y190 & $B a m \mathrm{HI}-B g l \mathrm{II}$ & 6552 & $\operatorname{pGEM} 3 Z f(+)$ & 1679 bp deletion \\
\hline pHIS2 & hisD & 1599 & Y223 & XhoI-EcoRI & 3525 & pGEM3Zf $(+)$ & 68 bp deletion \\
\hline pLYS3 & lys $A$ & 1293 & Y373 & Pst $\mathrm{I}-S m a \mathrm{I}$ & 3025 & $\operatorname{pGEM} 5 Z f(+)$ & Insertion \\
\hline pSELF23 & met $B$ & 1079 & Y75 & Pst I-EcoRI & 3608 & pUC18 & Insertion \\
\hline pPHE2 & pheA & $3838 c$ & $1 \mathrm{~A} 6$ & PvuII & 4322 & $\operatorname{pGEM} 5 \mathrm{Zf}(+)$ & 361 bp deletion \\
\hline pPRO7 & proC & 500 & $20 \mathrm{G} 9$ & BamHI-EcoRI & 4869 & pGEM3 & 198 bp deletion \\
\hline pTHR5 & $t h r B$ & 1296 & Y373 & Kpn I-Pst $\mathrm{I}$ & 3041 & pGEM5Zf $(+)$ & Insertion \\
\hline pTHR4 & thrC & 1295 & Y373 & $K p n \mathrm{I}-P s t \mathrm{I}$ & 3041 & $\operatorname{pGEM} 5 \mathrm{Zf}(+)$ & Insertion \\
\hline pTRP2 & $\operatorname{trpD}$ & $2192 c$ & Y190 & EcoRI & 5362 & pGEM $3 Z f(+)$ & 327 bp deletion \\
\hline
\end{tabular}

* Cosmids were obtained from the Sanger Centre and the indicated fragments subcloned into an E. coli cloning vector.

† The hyg gene from pAGAN40 (Hinds et al., 1999) was cloned into the indicated genes either as a straightforward insertion or by replacing part of the gene.

reading results. Auxotrophy was confirmed both by plating liquid cultures onto 7H10/OADC plates with and without individual amino acid supplements and by subculturing into unsupplemented 7H9/OADC/Tween broth and checking for lack of growth.

\section{RESULTS}

\section{Isolation of single crossover (SCO) homologous recombinants in amino acid biosynthesis genes}

The M. tuberculosis genome sequence (Cole et al., 1998) was used to select nine amino acid biosynthesis genes (Table 2), and knockout constructs were made in suicide plasmid vectors (plasmids that can replicate in E. coli, but not in mycobacteria). This was achieved by cloning each of the M. tuberculosis genes and inserting the byg gene either as a simple insertion or by replacing a fragment of the gene (Table 2). DNA samples from nine plasmids containing disrupted genes for aroK, $g \ln E$, hisD, lys $A$, met $B$, phe A, thrB, thrC and $\operatorname{trpD}$ were pretreated with UV or alkali and used to transform $M$. tuberculosis. The cells were plated onto 7H10/OADC medium supplemented with Casamino acids, and hygromycin-resistant $\left(\right.$ hyg $\left.^{\mathrm{R}}\right)$ transformants were obtained. Table 3 shows the total numbers of transformants obtained from one to four independent electroporations

\section{Table 3. Analysis of transformants using pre-treated suicide vector DNA}

Vector DNAs were pre-treated as described in Methods and used to electroporate M. tuberculosis. $\mathrm{Hyg}^{\mathrm{R}}$ transformants were selected on 7H10/OADC supplemented with Casamino acids, and Southern blotting was used to determine the genotype of each transformant. The figures shown are the totals from 1 to 4 electroporations per gene. The electroporation efficiencies with the replicating plasmid pATB12 varied from $10^{4}$ to $10^{6}(\mu \mathrm{g} \mathrm{DNA})^{-1}$.

\begin{tabular}{|c|c|c|c|c|}
\hline \multirow[t]{2}{*}{ Gene } & \multicolumn{2}{|c|}{ Alkali } & \multicolumn{2}{|c|}{ UV } \\
\hline & $\begin{array}{l}\text { Spontaneous } \\
\text { mutants }\end{array}$ & $\begin{array}{l}\text { Homologous } \\
\text { recombination }\end{array}$ & $\begin{array}{c}\text { Spontaneous } \\
\text { mutants }\end{array}$ & $\begin{array}{l}\text { Homologous } \\
\text { recombination }\end{array}$ \\
\hline $\operatorname{aroK}$ & 8 & 0 & 13 & 1 \\
\hline$g \ln E$ & 1 & 0 & 6 & 6 \\
\hline hisD & 0 & 0 & 2 & 2 \\
\hline lys $A$ & 5 & 0 & 13 & 2 \\
\hline met $B$ & 4 & 0 & 0 & $1^{*}$ \\
\hline pheA & 0 & 0 & 2 & 1 \\
\hline thrB & 1 & 0 & 2 & 2 \\
\hline $\operatorname{thr} \mathrm{C}$ & 0 & 0 & 5 & 9 \\
\hline $\operatorname{trpD}$ & 2 & 1 & 11 & 11 \\
\hline
\end{tabular}

* This was the only recombinant in which a DCO had taken place; all others were SCOs. 
Table 4. Analysis of transformants using pre-treated lacZ-suicide vector DNA

Vector DNAs were pre-treated as described in Methods and used to electroporate M. tuberculosis. $\mathrm{Hyg}^{\mathrm{R}}$ transformants were selected on 7H10/OADC medium supplemented with individual amino acids and X-Gal to score for blue and white colonies. The genetic structures of several blue colonies were confirmed as SCOs by Southern analysis. White colonies were streaked onto 7H10/OADC plates with or without amino acid supplement for auxotrophy testing. The figures shown are the totals from 2 to 5 electroporations per gene.

\begin{tabular}{|c|c|c|c|c|c|c|}
\hline \multirow[t]{2}{*}{ Gene } & \multicolumn{3}{|c|}{ Alkali } & \multicolumn{3}{|c|}{ UV } \\
\hline & Blue & White & Auxotrophs* & Blue & White & Auxotrophs" \\
\hline $\arg F$ & 36 & 11 & 0 & 25 & 1 & 0 \\
\hline$g \ln E$ & 100 & 19 & 0 & 400 & 8 & 0 \\
\hline hisD & 7 & 2 & 0 & 41 & 15 & 12 \\
\hline proC & 49 & 12 & 0 & 63 & 16 & 2 \\
\hline $\operatorname{trpD}$ & 16 & 1 & 1 & 115 & 35 & 35 \\
\hline
\end{tabular}

*All white colonies were tested for auxotrophy except with proC, where only 8 alkali-generated colonies and 7 UV-generated colonies were tested.

per gene. Transformants were grown up, genomic DNA was isolated, and Southern blotting was used to classify them as SCOs, double crossovers (DCOs), products of IR or spontaneous mutants (data not shown). Analysis of all 111 transformants showed that 35 were SCOs, one was a DCO, 75 were spontaneous hyg ${ }^{\mathrm{R}}$ mutants and none resulted from IR. Homologous recombinants were obtained at all nine loci. A DCO was obtained in the $m e t B$ gene only, with only SCOs occurring at the remaining loci.

Another group had found that Casamino acids are toxic to auxotrophs (Pavelka \& Jacobs, 1999). Our results were consistent with this observation, as we had only obtained a DCO mutant in one of the amino acid biosynthesis genes tested, and this one $(\operatorname{met} B)$ was actually prototrophic. Therefore, in later experiments we plated transformations onto media containing the appropriate amino acid as a supplement rather than Casamino acids.

\section{Isolation of DCOs using lacZ}

The large number of spontaneous hyg ${ }^{\mathrm{R}}$ mutants obtained prompted us to include the $l a c Z$ gene from $E$. coli as a screenable marker in the suicide vectors. This would enable us to identify SCOs in the initial transformation since they would form blue colonies on plates containing X-Gal and hygromycin; white colonies should arise from DCO events (as well as spontaneous hygromycin resistance). The lac Z gene was therefore cloned into three vectors already used (containing disrupted $\operatorname{trpD}$, hisD and $g \ln E$ genes) and two new suicide vectors were constructed, containing disrupted proC and $\arg F$ genes (Table 2). DNA was pre-treated with either UV or alkali and used in electroporations.

Results from several experiments are shown in Table 4.

\section{Table 5. Flanking DNA and sites of HR}

SCO transformants were analysed by Southern blotting and where possible the SCO structure was determined to see on which side HR had occurred. Flanking DNA length (bp) on each side of the hyg gene is given along with the site of HR. ND, not determined.

\begin{tabular}{|c|c|c|c|}
\hline \multirow[t]{2}{*}{ Gene } & \multicolumn{2}{|c|}{ Flanking DNA } & \multirow[t]{2}{*}{ Site of HR } \\
\hline & $5^{\prime}$ & $3^{\prime}$ & \\
\hline $\operatorname{aroK}$ & 954 & 1502 & $3^{\prime}$ \\
\hline$g \ln E$ & 3775 & 1098 & $5^{\prime}$ \\
\hline hisD & 1210 & 2247 & $3^{\prime}$ \\
\hline$l y_{s} A$ & 1677 & 1348 & $\mathrm{ND}$ \\
\hline met $B$ & 2867 & 745 & Both \\
\hline pheA & 2865 & 1092 & ND \\
\hline thrC & 440 & 2601 & $3^{\prime}$ \\
\hline $\operatorname{thr} B$ & 1452 & 1589 & $3^{\prime}$ \\
\hline $\operatorname{trpD}$ & 1783 & 3251 & $3^{\prime}$ \\
\hline
\end{tabular}

The total number of transformants was much higher than in the previous experiments, but the numbers were still very variable between experiments. Furthermore, the number of transformants obtained (and the ability to isolate recombinants) did not appear to correlate with the electroporation efficiencies obtained using replicating plasmids. For example, with the $g \ln E$ plasmid, on one occasion we obtained 200 blue and 2 white colonies $\left(10^{4}\right.$ c.f.u. per $\mu$ g replicating plasmid) and on another we obtained only 3 blue and 11 white colonies $\left(10^{5}\right.$ c.f.u. per $\mu \mathrm{g}$ replicating plasmid). We do not know what factors are responsible for this variation.

The many blue colonies obtained suggested that SCOs 
had taken place, and several clones were tested by Southern blotting to confirm this conclusion (data not shown). Since white colonies could have arisen either from spontaneous hygromycin resistance or from a DCO event, they were patch-tested for amino acid requirement. Several auxotrophs were isolated, occurring in three different genes: hisD, proC and $\operatorname{trpD}$. Auxotrophy was confirmed in liquid culture, and Southern blotting of three hisD, two proC and three $\operatorname{trpD}$ auxotrophic mutants confirmed the expected DCO genotype. Thus, in these cases, the lac $Z$ marker was useful since it showed that HR was taking place, as evidenced by the formation of SCOs, and allowed us to focus on the white colonies in screening for DCOs.

For $g \ln E$, a large number of blue colonies (500) from three experiments, but very few whites, were isolated. All of the white colonies were found to be spontaneous hyg $^{\mathrm{R}}$ mutants; the absence of any DCOs may indicate that this gene is essential for growth on the medium used. The use of lac $Z$ enables one to determine the frequency at which $\mathrm{HR}$ is taking place to produce SCOs, thus allowing a quick preliminary screen for essential genes - the absence of DCOs in such a large population of SCOs is indicative of HR, but suggests that DCOs may be lethal under the conditions used. No $\arg F$ mutants were isolated; the number of blue colonies was lower than that obtained with $g \ln E$, so there was less compelling evidence that a DCO would be deleterious in this case.

\section{DISCUSSION}

\section{M. tuberculosis mutants}

Four defined mutants have been constructed in amino acid biosynthesis genes by a method that uses nonreplicating DNA pre-treated with UV or alkali. Auxotrophic mutants are often attenuated (Cersini et al., 1998; Moral et al., 1998; Valentine et al., 1998), presumably because the bacteria live in an environment lacking that particular amino acid at some point during infection. Guleria et al. (1996) showed that M. bovis BCG auxotrophic for methionine, leucine or isoleucineleucine-valine are attenuated in mice. The mutants described in this paper are currently being tested for their ability to grow in macrophage/mouse models. As well as informing us about the in vivo environment, rationally attenuated strains can also be used as the basis for new vaccine production. They would also be useful general genetic tools, for example as markers, for the production of safer strains for genetic manipulation or for labelling of cell protein.

The met $B$ mutant obtained was not auxotrophic, showing no growth requirement for methionine. This gene encodes a putative cystathionine $\gamma$-synthase, which converts $\mathrm{O}$-succinyl-L-homoserine to cystathionine. One possible explanation is the possession of another gene/enzyme, that can complement or compensate for the loss of MetB activity. The complete genome sequence reveals that another gene (met $Z$; Rv0391) may also be a cystathionine $\gamma$-synthase, so it is possible that this gene product may have an overlapping function. Alternatively, the site of the $h y g$ gene insertion may not have inactivated the gene function, although the insertion lies near the $5^{\prime}$ end $(70 \mathrm{bp}$ downstream of the predicted start codon).

Initial attempts to construct defined auxotrophs by HR were unsuccessful. Only one DCO mutant was obtained and that was prototophic. The hisD auxotroph was tested for its ability to grow on media supplemented with Casamino acids and failed to grow, confirming that they are toxic at the concentration we used $(0.5 \%)$. This confirms the recent observations of Pavelka \& Jacobs (1999), and is an important consideration for other groups trying to isolate auxotrophs.

In the case of the SCOs analysed, the side on which recombination had occurred was that on which the flanking DNA was longer. The size ranged from $1.5 \mathrm{~kb}$ (aroK) to $3.8 \mathrm{~kb}(g \ln E)$. For the four DCOs where HR had necessarily occurred on both sides, the range of flanking DNA was from $0.7 \mathrm{~kb}($ metB) to $3.3 \mathrm{~kb}(\operatorname{trpD})$. Therefore, the need for regions of homology $>1 \mathrm{~kb}$ on each side of the mutated gene is not an absolute requirement, but is probably desirable. However, there is a trade-off in using longer flanking DNA to increase the efficiency of recombination since the efficiency of transformation is expected to fall with increasing plasmid size.

\section{IR and spontaneous mutants}

IR was not observed in any of these experiments. Care was taken to ensure that the restriction enzymes and probes used for Southern blotting would distinguish SCOs from illegitimate recombinants. IR has been one of the barriers to routinely obtaining gene knockouts, since it masks the low frequency of HR and requires that significant numbers of transformants are analysed in order to find the HR transformants which, for $M$. tuberculosis, is a laborious and time-consuming process. IR has been reported in M. tuberculosis (Kalpana et al., 1991; Pavelka \& Jacobs, 1999), M. bovis (Wilson et al., 1997) and M. bovis BCG (Aldovini et al., 1993; Kalpana et al., 1991), but now generally appears to be a nuisance rather than an overwhelming problem. The success of our method in attaining HR in 11 genes without any IR may be due to the fact that IR is not as big a problem as originally feared or that the method we use favours HR over IR, or it may be a combination of these factors.

Spontaneous resistance to hygromycin is potentially a problem because $M$. tuberculosis only has a single rRNA operon, and therefore is prone to resistance due to chromosomal mutations. Although the spontaneous mutation rate was reasonably constant, considerable variation in the efficiency of recombination for a given suicide vector was observed between transformations. As a result, the magnitude of the background problem caused by spontaneous mutants varied between experiments. However, this problem was largely overcome by 
including a second screenable marker, lacZ, in the vector.

\section{Differences in DNA pre-treatment}

UV pre-treatment was the more successful and technically easiest method, generating larger numbers of HR transformants than alkali pre-treatment. However, a potential drawback of UV treatment is that recombination with a DNA-damaged vector might result in the inadvertent introduction of secondary mutations. Although we have not directly tested for this, the fact that no lacZ mutants were identified amongst the large number of SCOs characterized in this study argues against mutagenesis of the integrated DNA occurring at a high frequency. Little, if anything, is known about the mutagenesis pathways that may operate in M. tuberculosis in response to DNA damage. A major mechanism for UV-induced mutagenesis in E. coli is via the umuCDdependent SOS-inducible pathway. No umuD has been identified in the M. tuberculosis genome (Cole et al., 1998; Mizrahi \& Andersen, 1998), suggesting that the SOS-inducible mutagenesis pathway is unlikely to be operative in this organism, although we cannot exclude the possibility that other inducible pathways exist (Humayun, 1998).

Alkali treatment was also successful in obtaining both SCO and DCO mutants, albeit at a lower rate. The difference in numbers of recombinants may reflect loss of DNA during precipitation or differences in the DNA substrates participating in the recombination events in vivo.

\section{Use of lacZ}

The inclusion of lac $Z$ into the suicide vector was an effective way of revealing colonies carrying plasmids integrated by SCOs. Thus, with lacZ it is possible to judge firstly if the experiment looks successful in terms of achieving any HR, and secondly, allows blue colonies to be ignored when looking for DCOs. If no DCOs are found, a blue (SCO) colony can be picked and plated for a second recombination event, although the inclusion of a negative selection marker such as $s a c B$ may be necessary (Pelicic et al., 1996).

\section{Conclusion}

We have developed a simple method for generating defined mutants of M. tuberculosis by HR and have demonstrated its general utility in this paper using 11 genes. This has allowed the isolation of four DCO mutants in amino acid biosynthesis genes.

\section{ACKNOWLEDGEMENTS}

The authors gratefully acknowledge the financial support of the Glaxo Wellcome Action TB Initiative, the South African Medical Research Council and the South African Institute for
Medical Research. We thank Selwyn Quan and Jason Hinds for helpful discussions, and the Sanger Centre for providing the cosmids.

\section{REFERENCES}

Aldovini, A., Husson, R. N. \& Young, R. A. (1993). The uraA locus and homologous recombination in Mycobacterium bovis BCG. J Bacteriol 175, 7282-7289.

Balasubramanian, V., Pavelka, M. S., Jr, Bardarov, S. S., Martin, J., Weisbrod, T. R., McAdam, R. A., Bloom, B. R. \& Jacobs, W. R., Jr (1996). Allelic exchange in Mycobacterium tuberculosis with long linear recombination substrates. J Bacteriol 178, 273-279.

Belisle, J. T. \& Sonnenberg, M. G. (1998). Isolation of genomic DNA from mycobacteria. In Mycobacteria Protocols, pp. 31-44. Edited by T. Parish \& N. G. Stoker. Totowa, NJ: Humana Press.

Cersini, A., Salvia, A. M. \& Bernardini, M. L. (1998). Intracellular multiplication and virulence of Shigella flexneri auxotrophic mutants. Infect Immun 66, 549-557.

Cole, S. T., Brosch, R., Parkhill, J. \& 39 other authors (1998). Deciphering the biology of Mycobacterium tuberculosis from the complete genome sequence. Nature 393, 537-544.

Guleria, I., Teitelbaum, R., McAdam, R. A., Kalpana, G., Jacobs, W. R., Jr \& Bloom, B. R. (1996). Auxotrophic vaccines for tuberculosis. Nature Med 2, 334-337.

Hinds, J., Mahenthiralingam, E., Kempsell, K. E., Duncan, K., Stokes, R. W., Parish, T. \& Stoker, N. G. (1999). Enhanced gene replacement in mycobacteria. Microbiology 145, 519-527.

Humayun, M. Z. (1998). SOS and Mayday: multiple inducible mutagenic pathways in Escherichia coli. Mol Microbiol 30, 905-910.

Kalpana, G. V., Bloom, B. R. \& Jacobs, W. R., Jr (1991). Insertional mutagenesis and illegitimate recombination in mycobacteria. Proc Natl Acad Sci USA 88, 5433-5437.

Mizrahi, V. \& Andersen, S. J. (1998). DNA repair in Mycobacterium tuberculosis: what have we learnt from the genome sequence? Mol Microbiol 29, 1331-1339.

Moral, C. H., del Castillo, E. F., Fierro, P. L., Cortes, A. V., Castillo, J. A., Soriano, A. C., Salazar, M. S., Peralta, B. R. \& Carrasco, G. N. (1998). Molecular characterization of the Aeromonas hydrophila aro $A$ gene and potential use of an auxotrophic aro $A$ mutant as a live attenuated vaccine. Infect Immun 66, 1813-1821.

O'Callaghan, D., Maskell, D., Liew, F. Y., Easmon, C. S. \& Dougan, G. (1988). Characterization of aromatic- and purine-dependent Salmonella typhimurium: attention, persistence, and ability to induce protective immunity in BALB/c mice. Infect Immun 56, 419-423.

Pavelka, M. S., Jr \& Jacobs, W. R., Jr (1999). Comparison of the construction of unmarked deletion mutations in Mycobacterium smegmatis, Mycobacterium bovis Bacillus Calmette-Guerin, and Mycobacterium tuberculosis $\mathrm{H} 37 \mathrm{Rv}$ by allelic exchange. J Bacteriol 181, 4780-4789.

Pelicic, V., Reyrat, J. M. \& Gicquel, B. (1996). Expression of the Bacillus subtilis sacB gene confers sucrose sensitivity on mycobacteria. J Bacteriol 178, 1197-1199.

Pelicic, V., Jackson, M., Reyrat, J. M., Jacobs, W. R., Jr, Gicquel, B. \& Guilhot, C. (1997). Efficient allelic exchange and transposon mutagenesis in Mycobacterium tuberculosis. Proc Natl Acad Sci USA 94, 10955-10960.

Sambrook, J., Fritsch, E. F. \& Maniatis, T. (1989). Molecular Cloning: a Laboratory Manual, 2nd edn. Cold Spring Harbor, NY : Cold Spring Harbor Laboratory. 
Santos, A. R., Demiranda, A. B., Lima, L. M., Suffys, P. N. \& Degrave, W. M. (1992). Method for high yield preparation in large and small scale of nucleic acids from mycobacteria. $J$ Microbiol Methods 15, 83-94.

Valentine, P. J., Devore, B. P. \& Heffron, F. (1998). Identification of three highly attenuated Salmonella typhimurium mutants that are more immunogenic and protective in mice than a prototypical aro A mutant. Infect Immun 66, 3378-3383.
Wilson, T., Wards, B. J., White, S. J., Skou, B., de Lisle, G. W. \& Collins, D. M. (1997). Production of avirulent Mycobacterium bovis strains by illegitimate recombination with deoxyribonucleic acid fragments containing an interrupted $a h p C$ gene. Tuber Lung Dis 78, 229-235.

Received 3 June 1999; accepted 20 August 1999. 